\title{
DEVELOPING EXTENSIVE READING THROUGH JIGSAW TECHNIQUE
}

\author{
Mohamad Mansur \\ Sekolah Tinggi Bahasa Asing - IEC Jakarta \\ Email:mansur@stibaiec-jakarta.ac.id
}

APA Citation: Mansur, M (2019). Developing Extensive Reading through Jigsaw Technique. Journal of English Language and literature, 4(2), 1-9. DOI 10.37110/jell.v4i02.74

Received: 22-06-2019

Accepted: 05-08-2019

Published:01-09-2019

\begin{abstract}
The purpose of this research is to find out the effectiveness of developing extensive reading through jigsaw technique students of a university in East Jakarta. The method used in this study was qualitative applying the four stages in reading Tales of Terror book. The result shows that each student could answer the comprehension questions with the average score is 86 . The students' achievement in reading comprehension of extensive reading by using jigsaw technique is quite good. The presentation stage shows that most students are able to deliver their understanding of the Tales of Terror book in a very systematic and clear explanation. Referring to the result of the presentation, the writer concluded that jigsaw technique is effective and applicable for the students of university.
\end{abstract}

Key words: Jigsaw, extensive reading, reading comprehension

\section{INTRODUCTION}

University students should have a reading habit. It is important because reading is one way to develop knowledge and to get information. Reading is the main activity for every student. It is because students are engaged with reading activities for every subject. In contrast, students feel reluctant to read, even sometimes are lazy to read. For some students seems to think that reading is a burden. They urge that they do not have enough time to do it. These troubles are due to the lack of motivation and the monotonous of the teaching reading. Besides, it is because some reading lists assigned by the their lecturers are often too long, Lecturers give too many obscure references and even if students were simply to follow up their main interests they would soon find (if they have not done so already) that there is too much information to absorb and too little time in which to absorb it. This condition makes students just read the text without knowing the essence of the reading.
For teachers, it is important to find out a way how to encourage students to read. Encouraging students is a much better than imposing. There some ways to stimulate students to read for example; by illustrating how to guess meaning of a word or expression, by showing the enjoyment of understanding a new issue, by introducing skimming and scanning technique instead of reading word by word or sentence by sentence. To comprehend a text alone (this is especially in extensive reading) is sometimes stuck on certain cases even if the student has consulted with the dictionary. To be willing to read, a prerequisite is needed i.e students like the subject. When students are interested in the subject they usually are kin to read. Though they like the topic, but they will still face problems especially to understand terminology which they are not familiar with. In this case teacher can facilitate by asking the students to read collaboratively. When students read collaboratively, they can learn together, share 
their information and opinions, even they can teach each other. It is therefore, worth trying to help students to read in a collaborative way. Besides, students can take the benefit of learning together, they can also strengthen their friendship and brotherhood. There are some ways how students learn together in an extensive reading activity. Among others is group assignment, group discussion, forming a learning group, and applying jigsaw technique.

Applying jigsaw technique enables students to take their own responsibility since students will have their own task in comprehending the text. In the first grouping students will read collaboratively until they know exactly what the text is about. The process of understanding the text is by reading and discussing with their friends. This process makes each member of the group takes participation in learning and makes the students feel free and enjoy doing the tasks. Considering at this explanation, the writer is interested to do a research using jigsaw technique to develop extensive reading to students of STIBA IEC Jakarta. By applying this technique, students will work in group of four or five depending on the reading materials as a team. The students are assigned to read some chapters, short books, or other materials which the students like the topics. Each team is randomly assigned to become an "expert" on some aspect of the reading assignment.

The objective of this research is to find out the effectiveness of developing extensive reading through jigsaw technique.

\section{REVIEW OF LITERATURE}

\section{The definition of extensive reading}

At the basic level, reading is sometimes thought to consist of translating meaning and pronouncing the words. This isn't reading at all. Some people wouldn't agree. However, it is clear that there is more to reading than merely being able to pronounce and give meaning to the words. Reading also comprises a range of other skills, including those that allow students to decide from context what is intended by words that can have more than one.

In language teaching, however, reading activities are sometimes classified as extensive and intensive. Extensive reading means reading in quantity and in order to gain a general understanding of what is read. It is intended to develop good reading habits, to build up knowledge of vocabulary and structure, and to encourage a liking for reading. Intensive reading, on the other hand is generally at a slower speed, and requires a higher degree of understanding than extensive reading. (Richards, Jack C. \& Richard Schmidt, 1985:212).

The reading class activities are often organized to learn grammatical items and comprehension questions. It becomes artificial because this does not meet the students need such as everyday life which students engaged with information in a form of reading text. Such close textual scrutiny seems to increase the anxiety that inhibits the reading flexibility of many students. Students come to believe that there is only one correct way to read, and this seriously hinders their studies.

\section{Reasons to read}

Students should know that reading in English is not a linguistic exercise quite different from reading in the students' own language. Outside the classroom the motivation to read is always influenced by a specific purpose the reader has in extracting the information that a text contains. In this case to facilitate students, teachers must seek to provide the materials and exercises that reflect the authentic purposes of the reading activities. The increase in a student's linguistic competence is thus gained only as a by-product. Extensive reading is therefore an activity done by someone who has purpose to gain specific information and it is done outside the classroom.

\section{Kinds of Reading}

Jeremy Harmer (2007) stated that there are two kinds of reading namely extensive reading and intensive reading. 
1) Extensive reading

The term refers to reading which students do often (but not exclusively) away from the classrooms. When it is possible, extensive reading should involve reading for pleasure or a joyful reading. This is enhanced if students have a chance to choose what they are willing to read.

2) Intensive reading

It refers to the detailed focus on the construction of reading texts which takes place usually (but not always) in classrooms. Teachers may ask the students to look at extracts from magazines, poems, Internet websites, novels, newspaper, plays, and wide range of other text genres. Intensive reading is usually accompanied by study activities.

\section{Reading Comprehension}

Reading is a general cognitive, problem-solving ability which underlies all language processing, including listening and is not specific to reading. Reading as a complex skill underlies all language process. As people learn their first language, the attention is primarily on the problem of decoding words. Therefore, people tend to think reading is as a process of looking at words, one after another and then adding them up to see what they (the words) mean. Reading comprehension is a very complex activity because so much occurs inside the mind of the reader as the eyes glide over the printed words. To accomplish a reading comprehension, it includes some skills to have. Reading comprehension is the process of acquiring or deriving meaning and understanding from printed language; involves cognitive functioning related to what one reads.

\section{Jigsaw Technique}

Jigsaw technique derives from the teaching model called cooperative Learning (C.L). C.L is not a new phenomenon in teaching learning process and it also provides some opportunities for the students to take more active role in their own learning. C.L requires the students to work in the small groups and it leads to a peer interaction. It also offers ways to organize group work to enhance learning and increase academic achievement. Based on a book entitled Techniques and Principles in Language Teaching, C.L (sometimes called collaborative learning) essentially involves students learning from each other in groups. The way that students and teachers work together make cooperative learning is distinctive from any other learning strategy. The teachers also teach the students collaborative or social skills so that they can work together more effectively.17 Cooperative learning can form the students to work in groups and the learning process that is done by working together is seen to be more effective.

The cooperative learning model was developed to achieve at least three important instructional goals: academic achievement, tolerance and acceptance of diversity, and social skill development. Cooperative learning requires a group learning that demands the students to work in groups and it also teaches some kind of social skills. The peer interaction among students also happened in the cooperative learning. Cooperative learning provides the students to work more actively in groups. Acikgoz on the journal from The Turkish Online Journal of Educational Technology stated that cooperative learning is a teaching method by which learners study by helping one another in the small groups in their learning process in order to achieve a common objective.

Jigsaw is one of the techniques used in cooperative learning. Jigsaw technique was first developed by Elliot Aronson in response to students' socialization problems in desegregated schools in the 1970s.23 Jigsaw has been used more than 30 years in U.S classrooms at all levels of schooling, including colleges and universities. The original intent of jigsaw technique is to provide children from diverse backgrounds the opportunity to work effectively and interpedently with one another. Jigsaw may 
be one of the most effective ways to observe, record, and assess students' improvement in some skills. Jigsaw also teaches students to be independent as they are given an assignment or puzzle to solve. The assignment is broken down into some small parts then students are assigned to discuss and to report the result of the discussion at the end of the jigsaw technique process.

The importance of working or discussing of a material with friends in groups (home and expert group) is very essential because each student is responsible for learning a portion of the material. Berkeley-Wykes on the journal of Journal of Education College, Helwan University defines that the jigsaw technique in reading as the technique in which a reading text is cut into segments and the task of the students is to restore it to its proper order to make sense of the text. The implementation of jigsaw technique in teaching reading is to break down the material into segments and what students should do is restore it to its proper order as the result of learning by using jigsaw technique. Jigsaw is a cooperative learning strategy that helps to build comprehension, and improve listening, communication, and problem-solving skills. This strategy is best to use when there is a large amount of text for students to read. From the statements above, the writer conclude jigsaw as a technique that is used in the classroom to build peers interaction and help to build problem solving skills.

\section{The steps of Jigsaw technique}

The stages in jigsaw technique are few and very straightforward. Students first work in expert groups to learn material they will be responsible for sharing their home groups later in the lesson. These are the stages in implementing jigsaw technique:

\section{a. Preparation}

In this stage, teachers have tasks to manage the time and the activity will be conducted. Teachers should prepare materials (expert reading and task sheets) and compose groups. b. Expert group

This stage requires teachers to move among groups to facilitate process, address content questions, and assess readiness for homegroup stage. This stage as well requires students to review or learn the material, accomplish any specific expert tasks, check expert-group members' understanding the material, decide how to teach expert content.

c. Home group

Teachers should move among groups to facilitate the process, address content questions as groups assemble the Jigsaw material, and assess readiness for full-class debriefing. Students' tasks in this stage are share or teach material.

d. Debriefing Some teachers' tasks in this stage are to conduct full-class discussion, to highlight specific content, to ensure that concerns of the home groups are addressed, and to assign homework or other follow-up tasks to groups or individuals. Students' tasks in this stage are to participate fully in the discussion, and to raise questions arising from the full-class discussion.

e. Group processing

In the group processing stage, teachers should provide time for small-group (expert or home group) or full-class discussion of the Jigsaw process, structure group processing with specific questions, and help students set goals to improve group work and social skills. Students' task in this stage are to focus on the improvement of ongoing home-group collaboration, to brainstorm improvements for the expert-group process, to brainstorm the improvements for the full-class discussion, and to set goals for improving group work and individual contributions.

f. Individual accountability This is the last stage of jigsaw technique, in this stage teachers' tasks are to design assessment to hold students accountable for what they learned (quiz, journal entry, 
project, homework). Students' task is to prepare for individual assessment.

\section{Advantages and disadvantages of Jigsaw Technique}

Carolyn Kessler mentioned some advantages of applying jigsaw technique in the classroom.

a. Provide opportunities for students to work in racially and culturally mixed groupings.

b. Provide an excellent learning environment for the acquisition of language through relevant content. c. Support the communicative approach in language teaching.

d. Develop students' skills of analysis, comparison, evaluation, and synthesis of information.

The advantages stated by Carolyn Kessler are mostly from the students because as students have main role in jigsaw technique process, students should get involved well in the process. Therefore, the ambience of learning process that provides the opportunities for the students to work in groups and to share ideas will likely to be effective. Besides, jigsaw technique can also enable the students to develop their skills. The advantages are mostly to improve students' reading ability in the term of comprehension.

Elliot Aronson (2013) also stated some advantages of jigsaw technique:

a. Most teachers find jigsaw technique easy to learn.

b. Most teachers enjoy working with it.

c. It can be used with other teaching strategies.

d. It works even if only used for an hour per day.

e. It is free for the taking.

The disadvantages are mostly seen in the students because each student somehow has different point of view in learning reading skill. The boredom, the ability to compete, and the inability to work in groups might distract the application of jigsaw technique. Moreover, if students find jigsaw technique is something new for them, it might take a quite long time to get familiar with jigsaw technique so the boredom might come up. According to the disadvantages mentioned above, teachers who are willing to apply jigsaw technique should get prepared for all of the possibillity that may happen.

\section{METHODOLOGY}

The jigsaw technique is applied to 20 students. Through the implementation of the technique, the writer observed whether the process match the theory discussed in part B. At the end of the project, the result is to be evaluated whether it could help students comprehend the content of the tasked assigned. Some findings are also to be written in verbatim way as documentation for further improvement.

The implementation started by choosing one of the Literature Work entitled "Tales of Terror". The reason why Tales of Terror book was chosen is because Tales of Terror is one of the literature works that all students learn. After selecting the chapters (four main chapters) to be assigned, the students are told the objective of the activity as well as the procedures of jigsaw technique. The activities include the following:

1. First grouping

The class is divided into four (4) groups (Group 1, 2, 3 and 4) consisting of five students. Each group is assigned to read one chapter respectively (G1: Chapter 1 , G2: Chapter 2, etc). This group is called expert group.

2. The students are asked to read their respective task at home, the next class session they are to discuss their comprehension. In this meeting the teacher asked the individual student in the group to make a summary of the chapter and to be presented on their respective group in the next meeting.

3 . The next activity is regrouping.

The class is regrouped into five groups consisting of four students. The four students in this regrouping are the representatives of the expert group. Therefore, the members of each group are 
student A from group 1 (chapter 1), student B from group 2 (chapter 2), student $\mathrm{C}$ from group 3 (chapter 3 ), and Student D from group 4 (chapter 4).

4. Have students present their chapter in groups applying controlled group (each of student $\mathbf{A}$ in the group begin the presentation continued by student $\mathbf{B}, \mathbf{C}$ and finally student $\mathbf{D}$. While a student is presenting his/her task before group, the other members of the group ask questions, clarification, give comments, feedback and additional information. This should go until they have the same perception in understanding the chapter.

5. When all groups finished their presentation and discussion, is the next session, the teacher then conducts the comprehension question test.

6. The last activity of this research was asked the five (5) groups to present the four chapter of the Tales of Terror book in front of the class.

During the whole process of jigsaw technique the teacher acts as facilitator, and her role include:

1. Help students how to skim and scan the text during the reading to the full process. Remind students to find other facts, information, and data needed in comprehending the text.

2. Encourage students to guess meaning when they cannot find the meaning in the dictionary.

3. In the discussion, the teacher asks each student in the group to take part in giving argument, opinion, understanding, point of view, as well as the important key points of the chapter. However, the teacher observes the process of discussion and reminds the active student not to dominate the talking in the group. The teacher also informs that in the cooperative language learning there is no smarter or less smart student in the group. All students are equal and should learn and success together.

4. In all the stages of jigsaw technique the teacher observes and take note both good findings as well as negative cases in a verbatim way. Later the result is to be evaluated and conveyed to the students as feedback.

5. Comprehension questions are to be made in two sets in which the level of difficulty and the weighing are more or less the same. The two set-tests are aimed at avoiding students of being cheated during the test. The test consists of 40 items of multiple choices comprising the four chapters.

6. In the presentation stage, teacher should encourage students to make preparation so that they can perform as interesting and clearly as possible. Teacher provides the rule of the discussion so that the time could be managed efficiently. During the presentation the teacher functions also as resource person to anticipate of answering the questions from other students.

\section{RESULT AND DISCUSSION}

Result

\section{a. Comprehension Test}

The following table shows the result of comprehension questions test.

Table 1: Comprehension tests result

\begin{tabular}{|c|c|r|r|c|c|}
\hline No, & Students & Scores & No. & Students & Score \\
\hline 1 & A & 89 & 11 & L & 77 \\
\hline 2 & B & 71 & 12 & M & 80 \\
\hline 3 & C & 82 & 13 & N & 83 \\
\hline 4 & D & 87 & 14 & 0 & 86 \\
\hline
\end{tabular}




\begin{tabular}{|c|c|c|c|c|c|}
\hline 5 & $\mathrm{E}$ & 84 & 15 & $\mathrm{P}$ & 85 \\
\hline 6 & $\mathrm{~F}$ & 91 & 16 & $\mathrm{Q}$ & 88 \\
\hline 7 & $\mathrm{G}$ & 93 & 17 & $\mathrm{R}$ & 95 \\
\hline 8 & $\mathrm{H}$ & 84 & 18 & $\mathrm{~S}$ & 89 \\
\hline 9 & $\mathrm{I}$ & 93 & 19 & $\mathrm{~T}$ & 90 \\
\hline 10 & $\mathrm{~J}$ & 20 & $\mathrm{U}$ & 92 \\
\hline \multicolumn{4}{|l|}{ Average score } \\
\hline
\end{tabular}

From table 1 above shows that no students get score under 70 . And the average score is 86 . It means that students can learn together during reading, discussion and group presentation.

\section{b. Whole class presentation.}

Table 2. Class Presentation score

\begin{tabular}{|c|l|l|l|l|l|l|}
\hline Group & $\begin{array}{l}\text { Language Use } \\
\text { accuracy\& } \\
\text { fluency) }\end{array}$ & $\begin{array}{l}\text { Presentation } \\
\text { strategy }\end{array}$ & $\begin{array}{l}\text { Content } \\
\text { Mastery }\end{array}$ & $\begin{array}{l}\text { Answering } \\
\text { Questions }\end{array}$ & Manner & Average \\
\hline 1 & Good & Excellent & Good & Fair & Good & Good \\
\hline 2 & Excellent & Excellent & Excellent & Good & Excellent & Excellent \\
\hline 3 & Excellent & Good & Excellent & Excellent & Excellent & Excellent \\
\hline 4 & Good & Good & Good & Good & Good & Good \\
\hline 5 & Fair & Good & Good & Good & Good & Good \\
\hline
\end{tabular}

Table 2 above indicates that most group count present well. It means that the students can comprehend the book as well as can

\section{c. Summary of verbatim notes}

1. Each student actively participated in the discussion and giving comments on their friends' opinion.

2. Students were egger to know all stories the chapter by consulting with the electronic dictionary. Students often asked the teacher about the literature terminology.

3. Students enjoy the discussion since they make some preparation before the discussion both in expert group as well as in regrouping session.

4. Though the teacher had reminded the active students, but they still sometimes dominated the discussion.

5. Students' vocabulary improved since they often used some new terms in the discussion.

6. Students focus more on content than on grammatical items or vocabulary. improve their comprehension on the Tales of Terror book.

7. Students show their cohesion when doing the reading to the full in the 'expert grouping'.

8. Students tend to compete with other group in the presentation session.

9. Students show their togetherness in learning.

10. Slow learners are encouraged to learn more by obtaining information from their friends, consult with the dictionary as well as ask question and clarification to the teacher. On the other hand fast learners tend to finish the task as quickly as possible.

\section{Discussion.}

\section{a. The success of the test}

Students were successful in taking the comprehension test as seen in the table 1 . Students got good score is because that they had undergone some steps such as reading individually, discussion, presenting the 
contents, and making summary of the chapter. These steps enable students to develop their understanding on the text and therefore could obtain a good score on reading comprehension tests. Referring to the theoretical background, it is proved that jigsaw technique enable students to learn and teach each other. This technique could also motivate students to read more seriously compared to other reading technique that apply only a single activity like reading and translating sentence by sentence.

To apply this technique teacher should make a good preparation such choosing the material, preparing comprehension test, facilitating and monitoring. In this research the teacher chose the Tales of Terror because it contains literature work and students are interested to read the book, and therefore the students like the topic. Since the material authentic, then students are willing to read and even do the reading to the full for several times.

\section{b. The presentation}

Table 2 shows that all groups perform their presentation well. From the teacher observation was that each group was competing to perform as well as possible, this is a positive learning atmosphere when student are willing to compete each other. However the key success of the presentation was the process of peer learning among the members of the group. As described by expert in part $B$ that the principles of jigsaw technique is learn and success together, so the presentation result in table 2 proves that jigsaw technique promote learning and facilitate students to do the extensive reading. In other words that jigsaw technique is feasible and effective to helping students to do the extensive reading.

\section{REFERENCES}

Anderson, J. C. (2000). Assessing Reading, Cambridge: Cambridge University Press,

Aronson, E. (2013) "Jigsaw Classroom", http://www.jigsaw.org/tips.htm,

\section{c. Other findings.}

The verbatim notes indicate that students were willing to read longer text. Students did the task in a serious and cohesive way. Students also enjoyed the activity such in discussion and sharing ideas. These students' attitude are the evidence that jigsaw could encourage self learning. Students were responsible for their duty and that's why each student showed did the preparation before joining their respective groups.

Considering the advantages and disadvantages of the jigsaw technique, it is proved that jigsaw requires the preparation from the teacher both choosing the right material for the students and designing the task, such as grouping, monitoring system and evaluation tools. Some notes on the verbatim also show the similarity of the advantages and disadvantages mentioned by Carolyn Kessler. Considering the disadvantages of the jigsaw technique, problem anticipation should be made by the teacher.

\section{CONCLUSION}

Founded on the process of jigsaw technique applied for university students in East Jakarta, it is concluded that jigsaw technique is effective and applicable for students of university to do the extensive reading. Peer learning happens during the process of doing the task. It also creates togetherness among the students. Jigsaw technique also stimulates students to read longer text. By doing such activity it is expected that reading become a habit to the students.

\section{Cruickshank, D.R (2006). The Act of}

Teaching. New York: The McGraw-Hill

Companies, Inc.

Dell', Olio., \& Jeanine M. (2007). Models of

Teaching. New Delhi: Sage

Publications.

Harmer, J. (2007). How To Teach English.

Kuala Lumpur: Longman. 
Journal of English Language and literature

Volume 4, Issue 2,September 2019

. (2007). How To Teach English, Kuala Lumpur: Pearson Education Limited.

Larsen-F.D., \& Anderson, M. (2011)

Techniques and Principles in Language Teaching. New York: Oxford University Press.

Lewin, L. (2003). Paving the Way in Reading and Writing. San Fransisco: JosseyBass.

McMillan, J.H., \& Schumacer, S. (2006).

Research in Education Evidence Based
p-ISSN 2540-8216, e-ISSN 2654-3745

https://journal.stibaiec-jakarta/ojs/index.php/jell

Inquiry 5th Edition. Boston: Allyn and Bacon.

Oshima, A. , \& Hogue, A. (2007).

Introduction to Academic Writing. New York: Pearson Education.

Richards, J.C., \& Renandya, W.A. (2002).

Methodology in Language Teaching: An Anthology of Current Practice. New York: Cambridge University Press.

Snow, D. (2007). From Language Learner to Language Teacher. Michigan: McNaughton \& Gunn, Inc. 